\title{
Fatty Acid Composition of Lagocephalus sceleratus (Gmelin, 1789) (Osteichthyes: Tetraodontidae)
}

\author{
Zahide Ulya NURULLAHOĞLU ${ }^{1 *}$, Esra ULUSOY ${ }^{2}$ \\ ${ }^{\prime}$ Marmara University, Faculty of Science and Arts, Biology Department, 34722, Kadlköy / Ístanbul \\ ${ }^{2}$ Selçuk University, Faculty of Science, Biology Department, 42151, Selçuklu / Konya
}

\begin{abstract}
Lagocephalus sceleratus is one of the worst invasive species in the Mediterranean Sea migrated from Red Sea and has been spreading throughout the area. The aim of this study is focusing on the potential nutritional use of this species. The long-chain polyunsaturated fatty acids docosahexaenoic acid (DHA) and eicosapentaenoic acid (EPA) are beneficial for health of humans. A good natural source of these fatty acids is seafood, especially fish. In this study, total lipid content and fatty acid composition of $L$. sceleratus were determined. Total lipid content of dorsal muscle was found as $1,82 \%$. Levels of EPA $(6,08 \%)$ and DHA $(15,68 \%)$ were found high. These results may mean that muscle of $L$. sceleratus has good nutritional value. After solving the toxicity problem of $L$. sceleratus, consuming this species as a food source may help to prevent the ecosystem againts this invasive species.
\end{abstract}

Key words: Lagocephalus sceleratus, fish oil, omega-3 polyunsaturated fatty acids, fatty acid composition.

\section{Lagocephalus sceleratus (Gmelin, 1789) (Osteichthyes: Tetraodontidae)'un Yă̆ Asidi Bileşimi}

\section{Özet}

Akdeniz'in en istilacı türlerinden biri olan Lagocephalus sceleratus Kızıl Deniz'den göç etmiş ve bölgede hızla yayılmaya devam etmektedir. Bu çalışmanın amacı, bu türün beslenme açısından olası kullanılabilirliğini belirlemektir. Uzun zincirli aşırı doymamış yağ asitleri; docosahexaenoic asit (DHA) ve eicosapentaenoic asit (EPA) insan sağlığı için faydalıdır. Bu yağ asitlerinin en iyi doğal kaynağı başlıca balık olmak üzere deniz ürünleridir. Bu çalışmada $L$. sceleratus'un toplam lipid miktarı ve yağ asidi bileşimi tespit edilmiş̧ir. Dorsal kasta toplam lipid miktarı \%1,82 olarak belirlenmiştir. EPA $(\% 6,08)$ ve DHA $(\% 15,68)$ yüzdeleri yüksek bulunmuştur. Elde edilen sonuçlar, L. sceleratus'un iyi bir besin değerine sahip olduğu anlamına gelebileceğini göstermiştir. L. sceleratus'un zehir etkisinin giderilmesinden sonra, bu türün besin maddesi olarak tüketilmesi, ekosistemi bu istilacı türden korumak konusunda yardımcı olabilir.

Anahtar kelimeler: Lagocephalus sceleratus, balık yağı, omega-3 aşırı doymamış yağ asitleri, yağ asidi bileşimi. 


\section{Introduction}

Fish lipids are well known to be particularly rich in long chain omega-3 polyunsaturated fatty acids (LC $n-3$ PUFA), especially eicosapentaenoic acid (EPA; 20:5n-3) and docosahexaenoic acid (DHA; 22:6n-3) [1-2]. LC n-3 PUFA have important role in human nutrition and development, disease prevention and health promotion [1, 3-4].

Phospholipids are the main component of the cell membrane and contain high percentage of PUFA. Diacylglycerol which has a key role in cell signaling is one of the lipid molecules into which EPA and DHA can be incorporated [5]. At sufficient levels of incorporation, EPA and DHA influence the nature of cell membranes, cell responses to external signals and gene expression in many cell types [6]. LC $n-3$ PUFA, especially EPA and DHA have been recommended for management of patients with coronary heart disease, diabetic cardiomyopathy, high blood pressure, rheumatoid arthritis, dementia, depression and Alzheimer's disease. Both EPA and DHA precursors of hormone- like substances. They play an important role in the development of neural functions, decrease inflammation and reduce plasma triglycerides. Their effects include also anti-thrombotic and endothelial relaxation [2, 5, 7-16] and can be used for prevention and treatment of cancer [17-18], and for the improvement of learning ability [19] and visual function [20].

Many investigations on health are focussing on lipid content and fatty acid composition of different fish species [1-2, 7, 21-24]. The Silverstripe Blaasop (Pufferfish), Lagocephalus sceleratus (Gmelin 1789) is a fish species of the Tetraodontidae family. It is distributed in the Indo-West Pacific Ocean and Red Sea. It is known that a breed of L. sceleratus is situated also in the Mediterranean Sea and Aegean Sea and migrates from Red Sea to Mediterranean Sea via Suez Channel which is the major route of migrating Indo- Pasific species [25]. It was first recorded in Gökova Bay-Turkey in 2003 [26-27]. The species was recorded in Antalya BayTurkey in 2004 and by the spreading rapidly, L. sceleratus had reached the Aegean Sea in 2006 [25, 28-30]. Last report for this species is from gulf of Gabès (Central Mediterranean, Tunusia) in 2010 [31]. This occurence suggests a succesful adaptation for westerly movement in to the Mediterranean Sea. Today, evidence shows that L. sceleratus is one of the worst invasive species in the Mediterranean Sea [25].

L. sceleratus is an aggressive predatory fish and is a serious hazard to humans since it contains tetrodotoxin (TTX). Tetrodotoxin (TTX) is a non-protein organic compound and one of the strongest marine neurotoxin. This toxin do not eliminates either with the hot or cooking $[25,32]$. TTX is generally taken up from food chain by the fish. An alternative explanation is that the toxin is produced by symbiotic or parasitic bacteria which the fish accumulate inside their bodies [25, 33-34]. Most of the toxin is concentrated in the liver, gonads, intestines and skin of fish [35]. And was also recorded occasionally in the muscles [25, 36]. Besides being poisonous the pufferfish is also strong and has a sharp beak that allows it to cut through fishermen's nets. On the another hand; Pufferfishes have rapidly spread and reproduced in the Mediterranean Sea in recent years and competes with native commercial carnivore species [25]. However, it is considered a delicacy in some countries (Japan, Malaysia, Taiwan, Korea, China, and some countries around Gulf of Suez) by cooks who know how to safely remove its skin and internal organs containing the poison. It is eaten exclusively in Japan, where is known with the name of fugu [31] and it is considered as the most delicious sea food in Suez City (Egypt) even it is illegal to sell [37]. 
Especially since L. sceleratus has been awared as in the list of the 100 "Worst Invasives" in the Mediterranean Sea [31, 38], we considered to determined the fatty acid profile of this species to get the information of its nutritional value. In this study, total lipid content and fatty acid composition of L. sceleratus obtained in Boğazkent, Antalya (Mediterranean Coast of Turkey) were determined.

\section{Material and Methods}

L. sceleratus samples used in the research were provided from fisheries immediately after hunted in Boğazkent, Antalya and it was carried out between June and July 2010. For determining the quantity of total lipid and composition of fatty acids $20 \mathrm{~g}$ sample of dorsal muscle of each fish was excised. Muscle samples taken from four different individual were studied at separate repetitions. Total lipid was extracted from samples by homogenizing in chloroform/ methanol $(2: 1, \mathrm{v} / \mathrm{v})$ and the total lipid content was determined gravimetrically after evaporation of the solvent and overnight desiccation in vacuo [39]. After total lipid quantity of samples had been determined, methylation of fatty acids for gas chromatography analysis was achieved.

Extractions, purifications and methylations of fatty acids and fatty acid analysis by gas chromatography were made at the laboratories of Scientific and Technological Research Council of Turkey (TÜBİTAK- Ankara, Turkey). Fatty acids extractions of samples were made by using the method of IUPAC (1979) [40]. For saponification of the fatty acids $2 \%$ $\mathrm{NaOH}$ solution was used and $14 \% \mathrm{BF}_{3}-$ methanol complex was added for methylation. Gas chromatography analysis for identification of the fatty acid methyl esters were made by using Agilent/HP 6890 GC with FID. DB-23 Column (capillary column coated with a cyanopropylstationary phase) was used for separations. In GC, the temperature of injector block was set at $250^{\circ} \mathrm{C}$ and detector block was set at $280^{\circ} \mathrm{C}$. Helium was used as carrier gas and temperature programming was from $50^{\circ} \mathrm{C}$ to $175^{\circ} \mathrm{C}$ at $25^{\circ} \mathrm{C} / \mathrm{min}$ and then to $235^{\circ} \mathrm{C}$ at $6^{\circ} \mathrm{C} / \mathrm{min}$ and kept for $15 \mathrm{~min}$ at $235^{\circ} \mathrm{C}$. Individual fatty acid methyl esters were identified by comparison with known standards. We took the mean of the data of four samples were taken from four different fish.

\section{Results and Discussions}

Total lipid content of the $L$. sceleratus was found as $1,82 \%$. Previous studies on fish lipid reported that total lipid contents of different fish species changing between 2-12\% [41]. Our results showed that total lipid content of $L$. sceleratus muscle was very low.

We determined that there were 21 fatty acids between lauric acid and DHA by gas chromatography analysis (Table 1). It is confirmed that the fatty acids which has the highest percentage in fatty acid composition are palmitic acid, steraic acid, docosahexaenoic acid, oleic acid, linoleic acid and eicosapentaenoic acid. Total percentage of omega-3 PUFAs was found as 27,91\%. Results showed that the levels of DHA $(15,68 \%)$ and EPA $(6,08 \%)$ of $L$. sceleratus were high. 
DHA and EPA are healthful in promoting growth and development in infants and young children and in reducing the risk of cardiovascular disease and adult psychiatric and neurodegenerative illnesses. DHA has an important structural role in the eye and brain [2-20]. On the basis of the beneficial effects of omega-3 PUFAs, recommendations have been made to increase their intake. Fish oil is a good natural source of DHA and EPA [24-42]. The composition and the level of PUFA depend on which these fatty acids are taken by food $[2,5$, 43]. Human may take the shorter- chain omega-3 fatty acid, $\alpha$-linolenic acid (ALA) from plants and can convert ALA into EPA and DHA, but this process is relatively inefficient [44]. EPA and DHA are not found in plants but are derived from especially fish. Therefore, the consumption of fish is recommended to satisfy dietary requirements for EPA and DHA [24]. We determined that the levels of DHA $(15,68 \%)$ and EPA $(6,08 \%)$ of $L$. sceleratus were significantly high. These results may mean that muscle of $L$. sceleratus has good nutritional value.

Table 1. Fatty acid composition of $L$. sceleratus muscle

\begin{tabular}{|lll|}
\hline Fatty acids & & $\mathbf{\%}$ \\
\hline C $12: 0$ & Lauric acid & 0,40 \\
C 14:0 & Myristic acid & 1,15 \\
C 15:0 & Pentadecanoic acid & 0,85 \\
C 16:0 & Palmitic acid & 20,74 \\
C 17:0 & Margaric acid & 0,51 \\
C 18:0 & Stearic acid & 16,27 \\
C 20:0 & Arachidic acid & 0,90 \\
C 14:1 & Miristoleic acid & 0,74 \\
C 16:1 & Palmitoleic acid & 1,09 \\
C 18:1 & Oleic acid & 14,52 \\
C 20:1 & Eicosanoic acid & 0,73 \\
C 22:1 & Erusic acid & 1,52 \\
C 16:2 & Hexadecadienoic acid & 1,42 \\
C 18:2 & Linoleic acid & 7,08 \\
C 22:2 & Docosadienoic acid & 1,86 \\
C 18:3 & Linolenic acid & 3,14 \\
C 20:4 & Arachidonic acid & 0,40 \\
C 20:5 & Eicosapentaenoic acid (EPA) & 6,08 \\
C 22:5 $\omega 6$ & cis-4,7,10, 13, 16- Docosapentaenoic acid & 1,34 \\
C 22:5 $\omega 3$ & Cis-7, 10,13, 16, 19- Docosapentaenoic acid & 3,01 \\
C 22:6 & Docosahexaenoic acid (DHA) & 15,68 \\
undefined & & 0,57 \\
\hline Total & & 100 \\
& & \\
\hline \hline$\omega 3$ fatty acids & 3,14 \\
\hline C 18:3 & Lauric acid & 6,08 \\
C 20:5 & Eicosapentaenoic acid (EPA) & 3,01 \\
C 22:5 $\omega 3$ & Cis-7, 10,13, 16, 19- Docosapentaenoic acid \\
C 22:6 & Docosahexaenoic acid (DHA) & 15,68 \\
Total & & 27,91 \\
\hline
\end{tabular}


In many countries, although landing of L. sceleratus is forbidden as a commercial species, they are illegaly landed and can be consumed since this species is relatively abundant in the Gulf of Suez and recently in Mediterranean as well. People may like such fishes because they are thought to be a very delicious, cheap and beneficial in potency as analgesic for backbone pain [37]. Additionaly, now we know that this species is one of good omega-3 fatty acid source. Consuming of this species may help to take its population under control and decrease the harmful effects on the ecosystem and commercial hunting.

On the another hand, since this species has toxicity, fishermen and consumers must be informed about the risk and the way of cleaning and dressed properly. Levels of TTX in fish may vary according to season, sex and organ tissue. Females were found to be generally more toxic than males and the highest toxicity levels were recorded in March which is the start of spawning season. Levels of TTX was found high in April, May, and June since these months are their spawning stage. L. sceleratus individuals range from not toxic at all to strongly toxic by size; smaller individuals being less toxic than large ones and toxicity increasing with age [25]. For decreasing the potential toxicity; the right season, the right size and the right age of the fish should be chosen. Choosing the younger individuals which has less toxicity may help to prevent the ecosystem againts this invasive species as well.

Recently, the absence of TTX toxicity in artificially reared puffer fish with non-toxic (without bacteria) diets is reported [25]. This study has not tried on L. sceleratus yet. Aquaculture and farming studies may try for this species to decrease of their toxicity. After all, still more information and investigations are required to decide for consuming this species as an food source.

\section{Conclusion}

Especially having the high level of omega-3 fatty acids in fatty acids composition of $L$. sceleratus, revealed that this species can be evaluated as a valuable nutrient. Additionally, it is important in terms of economy that it is cheap because it has not been preferred enough yet.

We think that it can be more useful to be sold in the markets after some special treatments and cleaning rather than hunting and consuming them individually that can cause toxication cases.

\section{Acknowledgements}

The authors thank Marmara University Scientific Research Committee (Project No: BAPKO FEN- D130612- 0242) for funding this research.

\section{References}

[1] Alasavar, C., Taylor, K.D.V., Zubcov, E., Shahidi, F. and Alexis, M. (2002). Differentiation of cultured and wild sea bass (Dicentrarchus labrax): total lipid content, fatty acid and trace mineral composition. Food Chemistry, 79, 145-150.

[2] Shirai, N., Suzuki, H., Tokairin, S., Ehara, H. and Wada, S. (2002). Dietary and seasonal effects on the dorsal meat lipid composition of Japanese (Silurus asotus) and Thai catfish 
(Clarias macrocephalus and hybrid Clarias macrocephalus and Clarias galipinus). Comparative Biochemistry and Physiology, Part A, 132, 609-619.

[3] Simopoulos, A.P. (1991). Omega-3 fatty acids in health and disease and in growth and development, a review. American J of Clinical Nutrition, 54, 438-463.

[4] Horrocks, L.A. and Yeo, Y.K. (1999). Health benefits of Docosahexaenoic acid (DHA). Pharmacological Research, 40, 211-225.

[5] Russel, F.D. and Bürgin- Maunder, C.S. (2012). Distinguishing health benefits of eicosapentaenoic and docosahexaenoic acids. Review Mar Drugs, 10, 2535-2559.

[6] Calder, P.C. and Yaqoob, P. (2009). Omega-3 polyunsaturated fatty acids and human health outcomes. Biofactors, 35(3), 266-272.

[7] Orban, E., Nevigato, T., Di Lena, G., Casini, I. and Marzetti, A. (2003). Differentiation in the lipid quality of wild and farmed Seabass (Dicentrarchus labrax) and Gilthead Sea Bream (Sparus aurata). J Food Science, 68(1), 128-132.

[8] Holub, D.J. and Holub, B.J. (2004). Omega-3 fatty acids from fish oils and cardiovascular disease. Mol Cell Biochem, 263(1-2), 217-225.

[9] Campbell, F., Dickinson, H.O., Critchley, J.A., Ford, G.A. and Bradburn, M. (2013). A systematic review of fish-oil supplements for the prevention and treatment of hypertension. European Journal of Preventive Cardiology, 20(1), 107-120.

[10] Gerber, P.A., Gouni-Berthold, I. and Berneis, K. (2013). Omega-3 fatty Acids. Role in metabolism and cardiovascular Disease. Current Pharmaceutical Design, 19(17), 3074-3093.

[11] Hegarty, B. and Parker, G. (2013). Fish oil as a management component for mood disorders- an evolving signal. Current Opinion in Psychiatry, 26(1), 33-40.

[12] Jafari, T. Fallah, A.A. and Azadbakht, L. (2013). Role of dietary n-3 polyunsaturated fatty acids in type 2 Diabetes: a review of epidemiological and clinical studies. Maturatis, 74(4), 303-308.

[13] Khan, R.S., Chokshi, A., Drosatos, K., Jiang, H., Yu, S., Harris, C.R., Schulze, P.C., Homma, S., Blaner, S., Shulman, G.I., Huang, L. and Goldberg, I. (2013). Fish oil selectively improves heart function in a mouse model of lipid- induced cardiomyopathy. $J$ Cardiovasc Pharmacol $^{T M}, 61,345-354$.

[14] Larsson, S.C. (2013). Dietary fats and other nutrients on stroke. Current Opinion in Lipidology, 24(1), 41-48.

[15] Pineiro- Corrales, G., Rivero, N.L. and Culebras- Fernandez, J.M. (2013). Role of omega-3 fatty acids in cardiovascular disease prevention. Nutricion Hospitalaria, 28(1), 1-5.

[16] Rix TA, Christensen JH, Schmidt EB (2013) Omega-3 fatty acids and cardiac arrhytmias. Current Opinion in Clinical Nutrition and Metabolic Care 16(2): 168-173.

[17] Carrol, K.K. (1990). Experimental and Epidemiological Evidence on Marine Lipids and Carcinogenesisi. In: Omega-3 Fatty Acids in Health and Disease, Lees, R.S., Karel, M. (eds.), Marcel Dekker, New York, 99-114.

[18] Laviano, A., Rianda, S., Molfino, A. and Fanelli, F.R. (2013). Omega-3 fatty acids in cancer. Current Opinion in Clinical Nutrition and Metabolic Care, 16(2), 156-161.

[19] Suzuki, H., Park, S.J., Tamura, M. and Ando, S. (1998). Effect of the long-term feeding of dietary lipids in the learning ability, fatty acid composition of brain stem phospholipids and synaptic membrane fluidity in adult mice: a comparison of sardine oil diet with palm oil diet. Mech Age Dev, 101, 119-128.

[20] Carlson, S.E. and Werkman, S.H. (1996). A randomized trial of visual attention of preterm infant fed docosahexaenoic acid until two months. Lipids, 31, 85-90.

[21] Sağl1k, S., Alpaslan, M., Gezgin, T., Çetintürk, K., Tekinay, A. and Güven, K.C. (2003). Fatty acid composition of wild and cultivated Gilthead Seabream (Sparus aurata) and Sea Bass (Dicentrarchus labrax). Eur J Lipid Sci Technol, 105, 104-107. 
[22] Su, X.Q., Antonas, K.N. and Li, D. (2004). Comparison of n-3 polyunsaturated fatty acid contents of wild and cultured Australian Abalone. International Journal of Food Sciences and Nutrition, 55(2),149-154.

[23] Kalay, M., Sangün, M.K., Ayas, D. and Göçer, M. (2008). Chemical composition and some trace element levels of Thinlip Mullet, Liza ramada caught from Mersin Gulf. Ekoloji, 17(68), 11-16.

[24] Chuang, L.T., Bülbül, U., Wen, P.C., Glew, R.H. and Ayaz, F.A. (2012). Fatty Acid composition of 12 fish species from the Black Sea. Journal of Food Science, 77(5), 512-518.

[25] Nader, M., Indary, S. and Boustany, L. (2012). FAO EastMed The Puffer Fish Lagocephalus sceleratus (Gmelin 1789) in the Eastern Mediterranean. GCP/INT/041/EC GRE- ITA/TD-10.

[26] Akyol, O., Ünal, V., Ceyhan, T. and Bilecenoğlu, M. (2005). First confirmed record of Lagocephalus sceleratus (Gmelin 1789) in the Mediterranean Sea. J. Fish Biol., 66, 11831186.

[27] Corsini, M., Margies, P., Kondilatos, G. and Economidis, P.S. (2005). Three new exotic fish records from the SE Aegean Greek Waters. Scienta Marina, 70(2), 319-323.

[28] Bilecenoglu, M., Kaya, M. and Akalin, S. (2006). Range expansion of Silverstripe blaasop, Lagocephalus sceleratus (Gmelin 1789), to the Northern Agean Sea. Aquatic Invasions, 1(4), 289-291.

[29] Kasapidis, P., Peristeraki, P., Tserpes, G. and Magoulas, A. (2007). First record of the Lessepsian migrant Lagocephalus sceleratus (Gmelin 1789) (Osteichthyes: Tetraodontidae) in the Cretan Sea (Agean, Greece). Aquatic Invasions, 2(1), 71-73.

[30] Carpentieri, P., Lelli, S., Colloca, F.C., Mohanna, C., Bartolino, V., Moubayed, S. and Ardizzone, G.D. (2009). Incidence of Lessepsian Migrants on landings of the artisanal fishery of South Lebanon. Journal of Marine Biodiversity Records, 2, 1-5.

[31] Jribi, I. and Bradai, M.N. (2012). First record of the Lessepsian Migrant Species and Lagocephalus sceleratus Gmelin, 1789) (Actinopterygii: Tetraodontidae) in the Central Mediterranean. BioInvasions Records, 1(1), 49-52.

[32] Arakawa, O., Hwang, D.F., Taniyama, S. And Takatani, T. (2010). Toxins of Pufferfish that cause human intoxications. Coastal Envrionmental and Ecosystem Issues of the East China Sea, 227-244.

[33] Kosuge, T.K., Tsuji, K., Hirai, K. and Fukuyama, T. (1985). First evidence of toxin production by Bacteria in an Marine Organism. Chem Pharm Bull, 33, 3059-3061.

[34] Simon, K.D., Mazlan, A.G. and Usup, G. (2009). Toxicity of Puffer Fishes (Lagocephalus wheeleri Abe, Tabeta and Kitahama, 1984 and Lagocephalus sceleratus Gmelin, 1789) from the East Coast Waters of Peninsular Malaysia. Journal of Biological Sciences, 9(5), 482-487.

[35] Ellenhorn, M.J. and Barceloux, D.G. (1988). Medical Toxicology, Diagnosis and Treatment of Human Poisining. Elsevier Science Publishing Company Inc. New York, 977pp. [36] Katikou, P., Georgantelis, D., Sinouris, N., Ptesi, A. and Fotaras, T. (2009). First report on toxicity assessment of the Lessepsian Migrant Puffer Fish Lagocephalus sceleratus (Gmelin, 1789) from European waters (Agean Sea, Greece). Toxicon, 54, 50-55.

[37] Sabrah, M.M., El- Ganainy, A.A. and Zaky, M.A. (2006). Biology and toxicity of the Pufferfish Lagocephalus sceleratus (Gmelin, 1789) from the Gulf of Suez. Egyptian Journal of Aquatic Research, 32(1), 283-297.

[38] Streftaris, N. and Zenetos, A, (2006), Alien marine species in the Mediterranean- the 100 "Worst Invasives" and their impact. Mediterranean Marine Science, 7, 87-118.

[39] Folch, J., Lees, M. and Sloane- Stanley, G.H. (1957). A Simple method for the isolation and purification of total lipids from animal tissues. J Biol Chem, 226, 497-509. 
[40] IUPAC. (1979). Standards Methods for Analysis of Oils, Fats and Derivatives. Paquot, C. (ed.), 6th edn, Oxford Pergamon Press, 59-66.

[41] Love, R.M. (1970). The Chemical Biology of Fishes. Academic Press, 2, London \& New York.

[42] Glomset, J.A. (1985). Fish, fatty acids, and human health. New England J of Medicine, 312(19), 1253-1254.

[43] Lemaitre- Delaunay, D., Pachiaudi, C., Laville, M., Pousin, J. and Amstrong, M. (1999). Blood compartmental metabolism of docosahexaenoic acid (DHA) in humans after ingestion of a single dose of $\left({ }^{13} \mathrm{C}\right)$-DHA in phosphatidylcholine. J Lipid Res, 40, 1867-1874.

[44] Heldt, H. (2005). Plant Biochemistry. An update and translation of the German third edition. Burlington, M.A. (ed.), Elsvier Academic Press, 630pp. 